\title{
GASTRONOMY AND TOURISM DESTINATION COMPETITIVENESS
}

\section{Slavka Drašković}

Singidunum University, Belgrade, Serbia
Correspondence:

Slavka Drašković

e-mail:

slavka.draskovic@singidunum.ac.rs
Abstract:

Although gastronomy as a science developed in close connection with tourism, research in the field of gastronomic tourism is quite rare. However, due to the increasing popularity of this type of tourism, one of the growing trends is precisely the research on food. Gastronomic tourism is gaining more attention each year, both in the scientific community and among users of tourism services. The purpose of this study is to determine the importance of gastronomic tourism for tourism destination competitiveness. The author argues that gastronomic tourism is one of the answers to the demands of new forms of tourism demand and that the culture, tradition and identity of the local community are an integral part of this kind of tourism. The study confirms the tendency of tourists to highly value local cultural values. Therefore, in developing destination competitiveness, one must take into account the global and the local component of gastronomic products.

Keywords:

gastronomic tourism, food, culture, destination competitiveness.

\section{INTRODUCTION}

Due to the specificity of food as a research subject, gastronomy uses research of other sciences. Today, it is impossible to explore the food only within a single discipline, but it is necessary to assume a multidisciplinary and holistic approach. Research in the tourism context is valuable for gastronomy as a relatively young discipline. For their part, this research must also take into account the research of other sciences, such as anthropology, history, and others. In this context, the paper establishes the framework for this and future research on gastronomic tourism and its impact on destination competitiveness. This framework includes not only tourist trips and tourist preferences, but also the role of culture, customs, and food symbolism and other characteristics of the local identity of a destination.

\section{TREND OF GROWTH}

Research in the field of gastronomic tourism is rare, and was primarily focused on the wine at the beginning, although these "oenotourists" are not necessarily those who engage in other, non-oenological gastronomic activities (Mak et al., 2012). Gastronomic tourism is a phenomenon in the 
making, because, among other things, more than a third of tourist spending goes to food (Quan \& Wang, 2004). This should not be surprising as the cuisine and food are of vital importance for the quality of vacation. Research has shown that eating in restaurants is the second most popular activity of tourists who visit the United States and the number one of free-time activities for American travelers when they visit other countries (WTO 2102).

According to the World Food Travel Association (WFTA), the growing demand for gastronomic ingredients while traveling is the result of several factors. The following are extracted from these factors: rapid growth of media and social media that deal with food; a farm-to-table movement among large travel brands and the increasing offer of high-profile events that promote local cuisine. The World Tourism Organization also reports that gastronomic tourism is becoming one of the leading trends with the high growth rate in all countries, and foresees that this growth rate will still increase (WTO, 2012)

\section{FOOD, CULTURE AND DESTINATION COMPETITIVENESS}

One of the definitions of gastronomic tourism defines it as experiential journey into gastronomic regions for recreation and entertainment, including visits to food producers, gastronomic festivals, food fairs, cooking shows and demonstrations, tasting quality food products or any tourist activity related to food (Hall \& Sharples, 2003). These experiential trips are in connection with certain lifestyle that involves experimentation, learning from different cultures, gaining knowledge and understanding of local products, history, culture and properties related to the tourism product.

Modern tourists are more experienced, have more money for the trip, and are willing to pay more to obtain new knowledge and unique experience. Contemporary forms of tourism that are developed in response to these changes in demand, offer them the opportunity to avoid the daily routine and sail into a new world, new culture, new aroma and tastes. The gastronomic experience is an integral part of the new experiences that are required. Modern tourists are going to popular destinations to enjoy the specific recipes and cuisine of this region, which makes gastronomy the central part of the tourist experience (WTO, 2012).

The food is the key feature of the culture of a nation and the region. The cuisine reflects the history and specificity of a given place. Its deep connection with his- tory, tradition, culture and religion of the site, makes it possible to promote destinations through the food. Thus, many destinations have started to advertise for its unique local cuisine, its ingredients and specialties. What is good is that the gastronomy is the competitive potential of each destination, because each has its own, ever-present specificity of local cuisine. It is only important for it to be recognized and smartly packaged as a tourism product.

Gastronomic tourism is particularly important for rural communities which, due to rapid urbanization, have a huge problem with economic growth. However, when it comes to food, these communities have a comparative advantage over others. First, they themselves produce food on their own land. This food is usually less polluted and healthier than the one produced en masse and with abundant fertilization. Second, these communities keep the longest tradition and culture of a region, and when it comes to food they keep the old recipes and traditional ways of preparing food. Tourism, and primarily gastronomic tourism, enables increase of income of the local community and employment to more people. There are new jobs such as local guides who visit the vineyards and local wine cellars (vineyard tour guides) or local chefs with tourists, and the food production and consumption in the agricultural sector and service sectors is also encouraged.

Food carries a symbolic meaning and has a social and class component (Fox, 2015). In the context of tourism, eating also has a 'symbolic' meaning. It is an indicator of social differences (Chang et al., 2011), and a symbol of our identity, the one by which we and our culture and community differ from others, their culture and community (Fox, 2015; Chang et al., 2011). Several studies have shown that the regional food and cuisine of a destination can be a powerful tool in their differentiation compared to other destinations, in terms of large global competition in tourism, as food contains a source of characters (Long, 2004; Frochot, 2003). Although it is expected that globalization leads to the increased homogenization, this is not the case with gastronomic tourism (Cavicchi \& Stancova 2016). This is very important when it comes to the competitiveness of the destination and confirms the tendency of tourists to highly value local cultural values. Therefore, in developing destination competitiveness, it is necessary to take care of this "glocalization" (global + local) and development of local gastronomic products (Cavicchi \& Stanco 2016; Chang et al., 2011).

Globalization is impossible if it is not localized, and it is one of the great paradoxes of modern globalization 
to the extent to which localization has become significant (Cavicchi \& Stanco 2016; Hall \& Sharples, 2003).

The trend in gastronomic tourism goes towards destination sustainability, further interest in local culture and tradition and authenticity of gastronomic experience, more expenses on food and drink, including gastronomic offers in combination with other forms of tourism. Gastronomic tourism shows the following tendencies (WTO 2015):

- environmental sensitivity and sustainability - Tourists are increasingly concerned about waste and packaging that remains after them, and recycle while traveling.

- local cuisine is still in trend - There is continued interest of tourists in the original local food and drink. More and more types of local are part of the tourism offer. These products are also increasingly represented at the airport terminals, train stations etc.

- willingness to pay more - Tourists spend on food and drink, in the context of the specific experience, they are willing to pay more than ever before.

- the search for new knowledge - Tourists are becoming more educated and are searching for something new and different. New knowledge and experience is required when it comes to food and drink, while looking for the new ingredients and products.

- authenticity - Whether the travelers explore the country, region, city, or their environment, they want to experience a destination through its inherent food.

- peer to peer experience when it comes to food - This concept has been promoted around the world by new online platform and enthusiastic food lovers around the world. Popular services offer online start- ups as Eat With, Feastly, MealSharing and CookApp, but Airbnb also included peer-to-peer dining in its offer. Online platforms link chefs who want to host dinner in their own homes to strangers who want a home-cooked meal. This type of experience also includes symbolic, cultural and social component of food because it contains the experience of food sharing, care, hospitality, friendship, dating and mixing with different social and cultural levels and more.

- the combination of wellness and gastronomic tourism - Wellness trips are increasingly integrated with tourism, food and beverages. A wellness tourist expects holistic approach to vacation, welfare and well-being as well as the specific lifestyle, and therefore fresher, healthier food choices in hotels, restaurants, airports etc. Also, these tourists take more tours with packages that include culinary adventures. (WTO, 2015)

Gastronomy has the ability to increase the tourism sustainability, strengthen the economy of a certain place, make the authenticity of the region and facilitate the creation of hospitable environment (du Rand et al., 2003).

\section{TOURISM, DESTINATION IMAGE AND GASTRONOMIC TOURISM EXPERIENCE}

The food could have mutiples roles in destination branding and setting:

1. Food is part of the marketing mix related to a destination because it helps in experiencing a certain place and allows you to literally taste the destination, coming directly into contact with the local culture;

2. Given that we eat two to three times a day, gastronomy is one aspect of the culture with which tourists usually come into contact. They try out the local culture.

3. Dietary habits are differences that immediately catch the eye: the time when people eat, how they eat and what they eat, everything becomes immediately different at the accession of a new culture.

4. Food allows direct contact with the landscape, because tourists can recognize its origin (Cavicchi \& Stancova, 2016).

Chang and his colleagues conducted the research which outlined 15 characteristics affecting the assessment of gastronomic experience at a destination. They are qualified in 6 categories, namely: tourists' own food culture, the contextual factor of dining experience, variety and diversity of food, perception of the destination, service encounter, and tour guide's performance (Chang et al., 2011, p. 311)

On the UNESCO's list of intangible cultural heritage, food has received the status of a true common cultural heritage. In this way, it gradually replaces the brand of geographic location (Williams et al., 2014) and becomes one of the most important components in the selection of a particular destination (Hall et al., 2003). Tourism offers more often include: the weekend of culinary school; dining in famous restaurants with the proven reputation; visits to rural markets and households; visits to food producers; organizing a street 


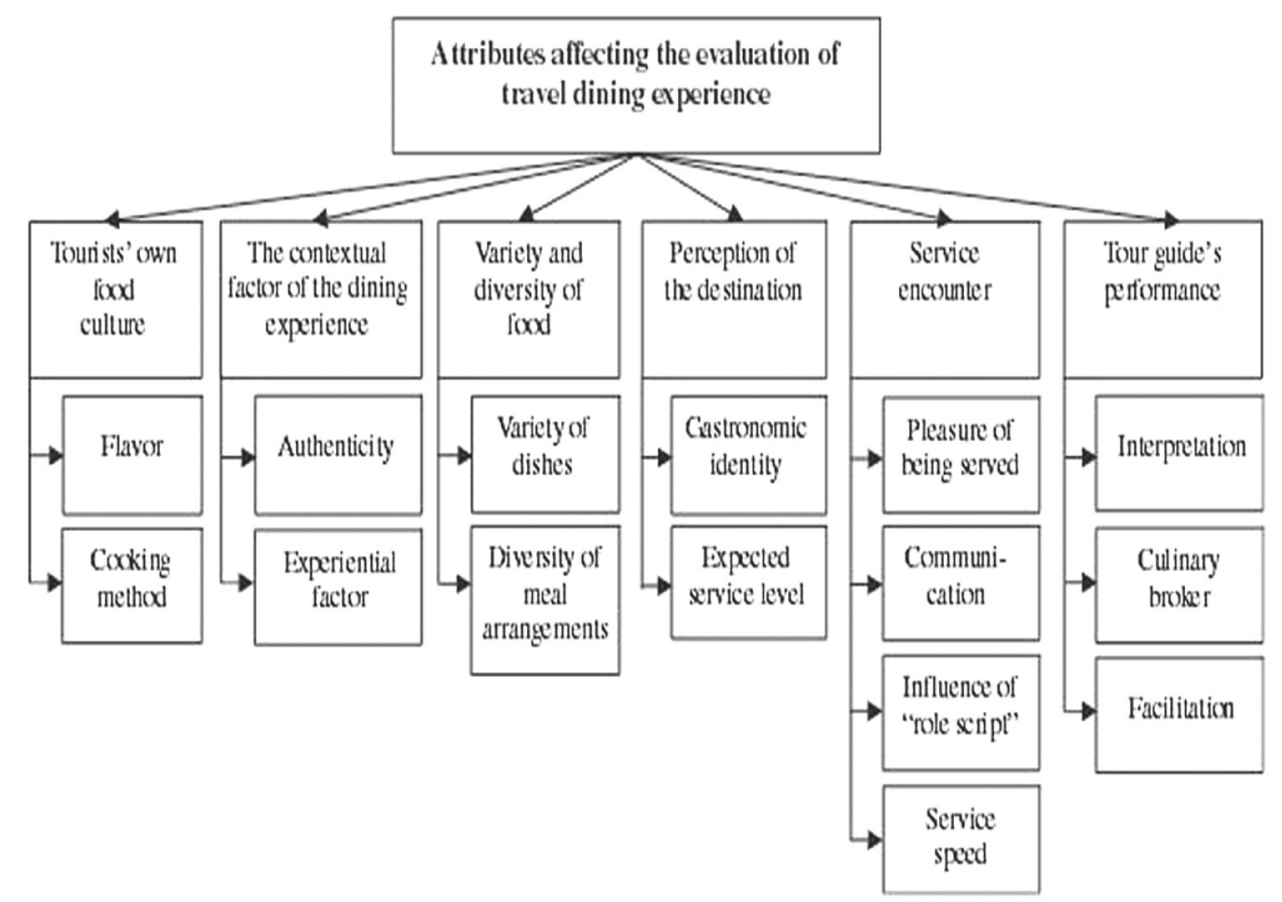

Figure 1. Attributes affecting the evaluation of travel dining experience Source: Chang et al. (2011, p. 311)

tour with food; organizing tours to festivals and worldfamous food-related events (like Gloucestershire cheese rolling festival or Tomato Throwing Tomatina Festival tours) etc.

UNESCO has established a network of cities "Creative Cities by UNESCO" that work towards promoting cultural diversity, where gastronomy is allocated as a separate thematic unit. This network includes 18 cities with the specific, live gastronomic community and local tradition in food preparation. In addition to these initiatives, a number of national and international associations have been established in recent years to strengthen the branding and attract international tourists (as a "Sustainable network of cities-food" in the UK, "Cities of food" in France, the project "Gastronomic cities" established by Urbact-European program for sustainable development of cities). The most widespread is still the oldest program "Cittaslow", created in 1997 in Italy, in order to expand the philosophy of slow food to local communities and their governments. Currently, more than 190 cities around the world are involved in this program.

\section{CONCLUSIONS}

Gastronomy tourism is one of the tourism market responses to the demands of the "new" tourist who wants to gain new experiences and knowledge on a trip. Components of the local are always included in food consumption in the tourism context. As gastronomic offer is an integral part of the culture of a nation and is often based on the national cuisine, local and folk elements, it contributes to the destination competitiveness.

In addition, tendencies in gastronomic tourism towards destination sustainability, further the interest in the local culture and tradition and authenticity of gastronomic experience, willingness of tourists to pay more for food and drinks, and the potential of combining gastronomic tourism with other forms of tourism (rural, wellness and spa tourism), and thus contribute to destination competitiveness.

\section{REFERENCES}

Almerico, G. (2014). Food and identity: Food studies, cultural, and personal identity. Journal of International Business and Cultural Studies, 8, 1-7.

Arnold, R., Berry, R., \& Bradley, E. (2000). A Century of Food Science. Chicago, IL: Institute of Food Technologists.

Ashley, B. (2004). Food and cultural studies. London: Routledge.

Barthes, R. (2008). Toward a Psychosociology of Contemporary Food Consumption. In C. Counihan and P. Van Esterik (Eds.), Food and Culture: A reader, (pp. 28-35). New York: Routledge.

Beardsworth, A., \& Keil, T. (1997). Sociology on the Menu: an Invitation to the Study of Food and Society. London: Routledge 
Bender, D., Ankeny, R., Belasco, W., Bentley, A., Mándala, E., Pilcher, J. M., \& Scholliers, P. (2011). Eating in class: gastronomy, taste, nutrition, and teaching food history. Radical History Review, 110, 197-216. doi:10.1215/01636545-2010-035

Bourdieu, P. (2010). Distinction: A social Critique of the Judgement of Taste. London: Routledge.

Cavicchi A., \& Ciampi Stancova, K. (2016). Food and gastronomy as elements of regional innovation strategies. Spain: European Commission. doi:10.2791/284013

Chang, R.C.Y., Kivela, J., \& Mak, A.H.N. (2011). Attributes that influence the evaluation of travel dining experience: When East meets West. Tourism Management, 32(2), 307-316. doi:10.1016/j.tourman.2010.02.009

Counihan, C., \& Van Esterik, P. (2008). Food and Culture: a reader. New York: Routledge.

Douglas, M. (1972). Deciphering a meal. Daedalus, 101 (1), 61-81.

Dallen, J.T., \& Amos, S.R. (2016). Religious heritage, spiritual aliment and food for the soul. In D.J. Timothy (Eds.), Heritage cousines: Traditions identities and tourism, (pp. 104-119). New York, NY: Routledge.

Dallen, J.T. (2016). Heritage, cuisines, foodways and culinary traditions. In D.J. Timothy (Eds.), Heritage cousines: Traditions identities and tourism,(pp. 1-25). New York, NY: Routledge. du Rand, H.A.(2003). The role of local and regional food in destination marketing: A South African situation analysis. Journal of Travel \& Tourism Marketing, 14(3-4), 97-112.

Frochot, I. (2003). An analysis of regional positioning and its associated food images in French tourism regional brochures. Journal of Travel \& Tourism Marketing 74(3-4), 77-96.

Hall, C.M., \& Sharples, L. (2003). The consumption of experiences or the experiences of consumption? An introduction to the tourism of taste. In C. M. Hall, E. Sharples, R. Mitchell, N. Macionis \& B. Cambourne (Eds.), Food Tourism Around the World: development, management and markets, (pp. 1-24). Oxford: Butterworth-Heinemann.

Mak, A.H.N., Lumbers, M., \& Eves, A. (2012). Globalisation and food consumption in tourism. Annals of Tourism research, 39(1), 171-196. doi:10.1016/j.annals.2011.05.010

Long, L.M. (2004). Culinary Tourism. Lexington: University Press of Kentucky.

Williams, H.A., Williams, R.L., \& Omar, M. (2014). Gastro-tourism as destination branding in emerging markets. International Journal of Leisure and Tourism Marketing, 4(1), 1-18.

World Tourism Organization. (2012). Global report on food tourism. Madrid: World Tourism Organization. 